\title{
Review: A guide to manufacturing CAR T cell therapies
}

\author{
Authors: Philipp Vormittag ${ }^{a}$, Rebecca Gunn ${ }^{b}$, Sara Ghorashianc and Farlan S Veraitch ${ }^{b}$ \\ a: Karlsruhe Institute of Technology \\ Institute of Engineering in Life Sciences \\ Section IV: Biomolecular Separation Engineering \\ Fritz-Haber-Weg-2 \\ 76131 Karlsruhe \\ Germany \\ philipp.vormittag@kit.edu \\ b: University College London \\ Department of Biochemical Engineering \\ Gower Street \\ London WC1E 6BT \\ United Kingdom \\ c: Molecular and Cellular Immunology Section \\ UCL Institute of Child Health \\ 30 Guilford Street \\ London WC1N $1 \mathrm{E}$ \\ United Kingdom
}

Conflicts of interest: none

This research did not receive any specific grant from funding agencies in the public, commercial, or not-for-profit sectors.

For correspondence, please refer to f.veraitch@ucl.ac.uk,+44 (0) 2076799569

Keywords: Chimeric antigen receptor modified T cells, manufacturing, state-of-the-art, platform, technologies, scale-up, scale-out, quality control, release testing 


\section{Abstract}

In recent years, chimeric antigen receptor (CAR) modified T cells have been used as a treatment for haematological malignancies in several phase I and II trials and with Kymriah of Novartis and Yescarta of KITE Pharma, the first CAR T cell therapy products have been approved. Promising clinical outcomes have yet been tempered by the fact that many therapies may be prohibitively expensive to manufacture. The process is not yet defined, far from being standardised and often requires extensive manual handling steps. For academia, big pharma and contract manufacturers it is difficult to obtain an overview over the process strategies and their respective advantages and disadvantages. This review details current production processes being used for CAR T cells with a particular focus on efficacy, reproducibility, manufacturing costs and release testing. By undertaking a systematic analysis of the manufacture of CAR T cells from reported clinical trial data to date, we have been able to quantify recent trends and track the uptake of new process technology. Delivering new processing options will be key to the success of the CAR-T cells ensuring that excessive manufacturing costs do not disrupt the delivery of exciting new therapies to the wide possible patient cohort.

\section{Introduction}

Over the last few decades, cell therapy has emerged as a promising new approach to treat malignancies that could only be treated on a palliative basis. Among those therapies, chimeric antigen receptor (CAR) modified T cell therapies proved to be effective for haematological malignancies [1]. To generate CAR T cells, patient- (autologous) or donor-derived (allogeneic) T cells are modified to express a CAR. The CAR is a chimeric construct containing at least one signalling domain of the T cell receptor and a single chain variable fragment (scFv) [2].

The production of autologous CAR T cells is carried out by a variety of manufacturing approaches all comprising the same common steps. First, the patient's white blood cells (WBCs) are isolated by leukapheresis and washed. Then, the T cells are activated, transduced with the CAR transgene, expanded to the required cell numbers for therapy, formulated and filled. After quality control testing and preparatory lymphodepleting chemotherapy for the patient, the product is injected into the patient.

Although the general outline of the process is similar in current trials, there are various options to carry out process steps during manufacturing of the CAR T cell product. The early stage of the current clinical trials mean that target cell numbers have not been established. Therefore, the scale of the process is still not defined. In addition, the degree of cell expansion varies from patient to patient and process to process. Recent estimates calculate an overall cost of 150,000-300,000 \$ for CAR T 
cell therapy products generated using current manufacturing approaches, whereas Novartis' Kymriah exceeds these estimates costing $475,000 \$$ per treatment [3]. It is therefore particularly important to recognize the major cost drivers and scale of the process, and current trends in manufacturing strategies.

This review aims to give an overview of CAR T cell therapy manufacturing with considerations of process scale and economics. Current published clinical trials on CAR T cell therapy are investigated in order to analyse the manufacturing strategies for CAR T cell products.

\section{Production technologies used in published clinical trials}

Outcomes of many clinical phase I and II studies are promising and with Kymriah of Novartis and Yescarta of KITE Pharma, the first CAR T cell products have been approved. However, research and development has still not created a mature, fully understood process and thus product. A number of CAR T products are manufactured using manual processing which is labour intensive, difficult to scale and prone to high failure rates $[4,5]$. This is mainly due to the personalised nature of CAR T therapies coupled with a lack of small-scale production technologies tailored for cell therapy coupled with a need to produce material for early phase trials quickly. Production processes consistently comprise of the same common steps shown in Figure 2.

\section{Leukapheresis, cell washing and enrichment}

\section{Leukapheresis and cell washing}

T cell therapy starts with obtaining the patient's WBCs by leukapheresis, an apheresis method that separates white blood cells from whole blood. The blood components are usually separated by density with continuous or intermittent centrifugation methods using density gradient media.

Anticoagulants added during the apheresis process, red blood cells and platelets are contaminations which are usually removed in a washing step. Anticoagulants potentially alter the behaviour of the cells during activation [6], red blood cells can influence clinical efficacy and platelets can lead to clumping of the cells $[7,8]$. To remove red blood cells and platelets, manual Ficoll density gradient centrifugation is applied in early reports and again in more recent clinical trials (NCT01886976; NCT01864902) [9-11]. Alternatively, automated cell-washers such as the COBE 2991 Cell Processor (Terumo BCT, Lakewood, CO, USA) [12] (NCT02215967), the Haemonetics CellSaver (Braintree, MA, USA) [13], the discontinued Baxter Cytomate [14] (NCT00466531, NCT01044069), the Biosafe Sepax II $[15,16]$ (NCT00968760, NCT01497184, NCT01362452) or the monocyte depleting CaridianBCT Elutra [17] (NCT01029366) are used. After washing, the WBCs are either directly used or frozen in controlled rate freezers such as the Cryomed [14]. 


\section{Enrichment and depletion}

Some groups enrich for or deplete specific cell subsets using the CliniMACS system with the respective antibody linked to paramagnetic beads. The Fred Hutchinson Cancer Research Center and Seattle Children's Hospital enrich WBCs for CD4 ${ }^{+}$(T helper cells) and $\mathrm{CD} 8^{+}$(cytotoxic T cells) in order to infuse a product with a defined $\mathrm{CD} 8^{+} / \mathrm{CD}^{+}$cell ratio (Gardner et al. 2014, Turtle et al. 2014, 2015a, 2015b; Reference in Table 2). Similarly, Brown et al. (2016) (Ref. Table 2) opted to produce treatment that was enriched for central memory $T$ cells $\left(C D 62 L^{+}\right)$. Singh and colleagues from MD Anderson Cancer Center found that high numbers of natural killer (NK) cells impede T cell culture

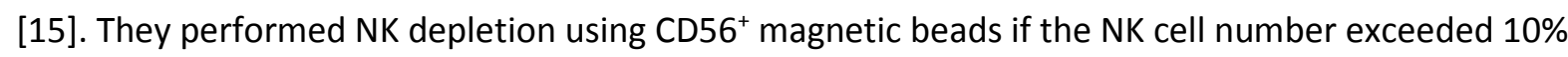
in the process. Ramos et al. (2013) (Ref. Table 2) performed CD3 ${ }^{+}$selection in two patients that had $>95 \%$ circulating leukemic cells to enable expansion from an apheresis product containing a low percentage of T cells.

\section{Activation}

In vivo, naïve T cells are stimulated for proliferation and differentiation by antigen presenting cells such as dendritic cells (DCs). T cells are activated by interactions between the T cell receptor (TCR) and the major histocompatibility complex located on the DC cell surface and through costimulatory molecules such as CD28, 4-1BB and OX40 [18]. To avoid the cumbersome process of co-culture with DCs, several methods that mimic the natural stimulation of T cells have been developed and implemented [13].

\section{Monoclonal antibodies and interleukins}

A common approach is to add OKT3 (anti-CD3 monoclonal antibody (mAb)) and interleukin (IL) 2. Simultaneous co-culture with irradiated healthy donor peripheral blood mononuclear cells (PBMCs) and lymphoblastoid cell lines (LCL; human Epstein-Barr-virus (EBV) infected PBMCs) [19] is sometimes referred to as the 'rapid expansion protocol' [20]. The concentration of IL-2 used varies considerably from one trial to the next. Gattinoni et al. 2011 [21] suggest that the use of IL-2, especially in excessive concentrations, can lead to an exhausted T cell product that has entered into stages of dysfunction, displaying poor effector function and quickly approaching apoptosis [22]. Barrett et al. (2014) [23] and Ghassemi et al. 2016 [24] found that replacing IL-2 with IL-7 and IL-15 resulted in a higher percentage of memory subsets.

\section{Cell-sized anti-CD3/CD28 antibody coated magnetic beads}

Kalos et al. (2011) [17] used anti-CD3/CD28 antibody coated magnetic beads as artificial antigen presenting particles and found that activation with these allows for engraftment of cells that retain their memory phenotype more than with OKT3/IL-2. The superparamagnetic beads have a diameter of $4.5 \mu \mathrm{m}$ and are efficiently removed with a strong electromagnet, leaving $<100$ residual beads per $3 \times 10^{6}$ cells at the end of production, as shown by Hollyman et al. (2009) [14]. During expansion, the 
beads were used to continuously stimulate the cells. Cytokine production was 10-100 fold higher suggesting that activation is stronger using bead-activation compared to other methods such as activation with anti-CD3 antibodies and IL-2 [13,25]. Antibody-coated paramagnetic beads also present several processing advantages. By magnetically retaining the beads bound with cells, cell culture steps such as washing and enrichment are more easily facilitated. The beads can be used for selection and activation of the cells without the need to remove them until harvest. Perfusion or media exchange is possible without losing great amounts of expensive stimulating antibodies since they are coupled to the beads. It has been shown, that activation with anti-CD3/CD28 beads results in less exhausted and thus more persistent T cells than activation with OKT3 (anti-CD3 mAb) and IL-2 [23].

\section{Artificial antigen presenting cells}

In a few recent clinical studies CAR-T cells were activated with non-viable antigen presenting cells, such as $\mathrm{K} 562$ cell lines that co-express the desired stimulating molecules and a tumour-associated antigen (TAA) [16]. Irradiated, the dead cells are compliant with current good manufacturing practice (cGMP). They do not express human leukocyte antigen $A$ and $B$ and selectively stimulate the CAR T cells specific for the TAA $[16,26]$. For generation of CAR T cells with EBV-specific TCRs, EBV transformed LCL are used for activation [27].

\section{Activation in current clinical trials}

We investigated the frequency of use of different technologies for the manufacturing of the products used in clinical trials (listed in Table 1). To the best of our knowledge, data from all trials published from 2002 to September 2017 were analysed in this study. If the number of patients was not specified or neither process technology nor product characteristics were detailed in a publication, it was not included in this analysis. The term 'evaluable product' describes a product given to one patient and that is reported as activated, transduced or expanded in a certain way. A CAR T cell product that is reported with indistinct or no data is not an 'evaluable product'. Studies that were reported without any details on the manufacturing process were excluded. In total, manufacturing data of products for 1000 patients have been analysed.

The dominant method for activation of the T cells is the activation with anti-CD3/CD28 antibodycoated paramagnetic beads with 626 out of 952 evaluable products. Anti-CD3/CD28 mAbs and IL-2 were used for 279 of 952 evaluable products, 107 of which were KTE-019 by KITE Pharma (now approved as Yescarta). The first groups to report the use of magnetic beads in the reviewed studies were Deeks et al. [28] (2002) in a study on anti-gp120 CAR T cells for HIV. The high number of studies using this approach is associated with Novartis and Juno Therapeutics products CTL019 (now approved as Kymriah) and JCAR014, JCAR015, JCAR017 and JCAR018. 


\section{Gene delivery}

Gene delivery can be divided into viral and non-viral methods. In CAR T cell therapy, electroporation of naked DNA, plasmid-based transposon/transposase systems and viral vectors, in particular retroor lentiviruses have been applied for gene delivery (Table 1 ).

\section{Viral transduction}

A retro- or lentiviral gene transfer can result in high transduction efficiencies (anywhere between 4$70 \%$ in investigated studies $[11,29])$ but is significantly more expensive than plasmid transfection. High efficiency transduction using retro- or lentiviruses requires activation of the T cells. Especially in retroviruses, that only transduce dividing cells, proliferation is essential for gene delivery. With both approaches, there is a risk of oncogenic gene insertion, while lentiviral integration is theoretically less prone [30]. However, to the best of our knowledge, no such cases have been reported in the clinic with CAR T cell therapy.

Viral gene delivery methods require packaging cell lines for the cGMP production of the viral vector. This is labour intensive and expensive mainly because vector production has to be carried out in a separate clean room facility and additional vector release testing has to be performed. Lentiviral vectors are typically produced via transient transfection using large amounts of plasmid DNA; making them more expensive than retroviral vectors that can be produced using stable packaging cell lines $[31,32]$. Development of stable packaging cell lines, such as WinPac, for lentiviral vector production may reduce this cost [33]. Furthermore, viral vectors require costly testing for replication competent virus resulting in costs of several ten thousand dollars per patient [31]. The production of both retroviruses and lentiviruses has been reviewed in detail elsewhere [34].

\section{Plasmid-based gene delivery}

A relatively new method of CAR gene delivery is the use of transposon/transposase systems. A transposon is a sequence of DNA with the ability to change position within a genome via transposase excision and insertion [35]. The CAR transgene can be inserted into a transposon sequence on a plasmid, with the transposase encoded either within the transposon or separately. Plasmids are electroporated into T-cells prior to activation, where then the transposase excises the CARcontaining-transposon and inserts the sequence into the T-cell genome $[26,36,37]$. The use of a transposon system was found to increase the efficiency of gene integration in comparison to the electroporation of naked DNA, giving efficiencies closer to that of viral transduction [16].

The Sleeping Beauty (SB) transposon/transposase system has been used to produce CAR T-cells. This method of gene delivery eliminates the requirement for clinical grade viral vector generation and is comparably inexpensive [31]. One drawback is that the culture-time for generation of required cell numbers is higher than with virus transduced CAR T cells [36]. It is important to note that, as with 
viral gene delivery methods, insertion of the gene can lead to oncogenesis or disruption of other relevant genes [38]. However, in a recent study, SB gene integration into T cells was considered the method with the lowest chance of insertional oncogenesis compared to viral methods and the piggyBac transposon/transposase system [39]. The first in-patient use of the SB transposon/transposase system for CAR T-cell therapy has shown promising outcomes [26,37].

\section{Gene delivery in current clinical trials}

Viral transduction is the most common gene delivery method with 919 of 978 evaluable products

(Figure 3). Lentiviral transduction is predominant with 521 products whereas retroviral transduction is the second most used method with 398 products. With both methods, safe and efficacious products can be generated with high transduction efficiencies but they are somewhat expensive. Early studies with simple plasmid DNA transfection yielded less impressive clinical results $[9,10,40]$. Methods based on a transposon/transposase system (i.e. the SB system, see above) entered the clinics more recently treating 39 patients. If it can be proved that creating a safe and efficacious product using this route is feasible, this approach becomes particularly interesting for the field of CAR T cell therapies as transposon/transposase based gene delivery offers significant economic advantages over viral transduction [31].

\section{Expansion}

T-Flasks and static culture bags

During expansion of transduced or transfected CAR T cells, the culture volume is changed. With increasing numbers of cells either vessels with increased volume or a greater number of vessels are used, e.g. multiple tissue culture plates or flasks $[9,10]$. This is labour intensive since flasks need frequent medium changes by trained operators in clean rooms or biosafety cabinets (class 100 environment) [5]. Using tissue culture plates or flasks is not suitable for large-scale manufacturing as it involves a plurality of open-handling steps and is not acceptable as an industry standard at the state of the art. Static culture bags are commonly used for expansion (Table 1) and can be connected by tubings in a sterile way. Tumaini et al. (2013) [41] developed a semi-closed system that minimises open-handling interaction by using connected static culture bags. Static culture bags are comparably easy to implement and are suited better for manufacturing than tissue culture flasks, as sample and media transfer requires less manual open-handling, increasing safety.

\section{The rocking motion bioreactor}

The rocking motion (RM) bioreactor (e.g. WAVE bioreactor/Xuri Cell Expansion System) further minimises operator interaction by application of a media perfusion regime. A perfusion regime removes growth-inhibiting substances and ensures constant amounts of nutrients; thus, enabling culture in smaller volumes than with static culture bags [42]. Sadeghi et al. (2011) [43] found that using a RM bioreactor system instead of static culture bags to expand TILs reduced labour intensity 
to $33 \%$ and media consumption to $50 \%$. Interestingly, it has been observed that using RM bioreactor systems results in a final product comprising more $\mathrm{CD}^{+}{ }^{+} \mathrm{T}$ cells [44]. Scaling up is a challenge with this type of bioreactor and mechanical failure of the rocking device can result in a batch failure [44]. The Xuri technology offers the advantages of (semi-)automated production.

\section{Expansion in current clinical trials}

In current cell culture processes, the media volume is usually increased; typically by increasing the size of a bag or flask or by changing from plates to flasks, flasks to static culture bags or static culture bags to a RM bioreactor. The variety of methods in the expansion process can be divided into three approaches. First, 147 of 679 evaluable products were expanded using plates or T-flasks ('T-Flasks' in Figure 3). This approach has a high requirement of trained operators manufacturing the product in an open-handling manner in safety cabinets usually using multiple flasks/ plates per product [5]. Tissue culture flasks and plates are used for smaller patient cohorts in particular. 237 products were expanded in static culture bags, or eventually scaled up to static culture bags after initiating expansion in flasks or plates ('Static Culture Bags' in Figure 3). Scaling up using larger static culture bags instead of increasing the number of flasks or plates has a number of advantages. In particular, bags can be connected in a sterile way reducing the amount of open-handling steps [41]. The third approach utilises the most advanced technology. Starting in bags or flasks, the expansion finally takes place in a RM bioreactor that runs in perfusion. With 295 of 679 evaluable products, the RM bioreactor approach for expansion is prevailing, which was due to its use in larger patient cohorts.

Common combinations of activation, gene delivery and expansion methods in current clinical trials As shown in Figure 3, with 295 of 679 evaluable products (43\%), the combination of bead activation, viral transduction and expansion in the RM bioreactor is most common production method (CTL019, JCAR014, JCAR017 and JCAR018 playing a major role). The second most frequent approach, with 129 products (19\%), is activation with mAbs/IL-2, viral transduction and expansion in flasks. This approach is the most manual and unautomated production strategy. Third most used is the combination of bead activation, viral transduction and expansion in static culture bags (119 products, 18\%). Our analysis reveals that the overall culture process typically has a duration of $<20$ days (Figure $1)$.

\section{Challenges and novel solutions in CAR T cell therapy manufacturing}

\section{Messenger RNA Transfection and other means to control CAR function}

Off-tumour on-target toxicities are potential fatal risks when testing novel receptors in clinical trials [45]. Solutions to mitigate these risks include messenger RNA (mRNA) transfection of the T cells, so that they express the CAR only in a transient manner limiting the effect of CAR toxicity issues [4547]. Repeated infusions of mRNA have been shown to successfully induce antitumor activity in 
patients [47]. Another design includes a drug dependent "kill switch" for inducible apoptosis, useful for mitigating long-term off-tumour toxicities such as B cell aplasia in CD19-CARs [48]. This approach was applied in the clinical trial NCT02028455, in which T cells were transduced with the suicide construct EGFRt, in addition to the CAR (Gardner et al. 2016, Ref. Table 2) [49]. Other designs have been reviewed further elsewhere [50].

\section{Variability and the lack of a defined process scale are major challenges}

Current processes use a variety of technologies, which, as already discussed, can lead to variations in subset composition in the final product. Additionally, primary apheresis products are individually different for each patient. Brentjens et al. (2011) [29] reported anywhere between 23.6-385-fold expansion in ten patients. Interestingly, the two extremes of expansion were achieved in almost the same culture time. 23.6-fold expansion was achieved in 18 days and 385-fold expansion in 16 days, with the final dose being $1.1 \times 10^{9}$ and $1.4 \times 10^{9} \mathrm{CAR}$ T cells, respectively. The varied expansion rates obtained are indicative of the considerably different and unpredictable behaviour of the cells. The variability of the process is also apparent in the reported transduction efficiencies. In the same study, retroviral transduction resulted in efficiencies of 4-70\% [29]. Guo et al. (2015) [11] obtained lentiviral transduction efficiencies from $5.5 \%$ to $45.3 \%$, with other groups reporting similar [51,52]. This inherent variability makes it difficult to compare between studies and manufacturing platforms. It is also important to note that the design of the CAR molecule varies between the studies. For detailed reviews on the design of CAR T cells the reader is referred to Sadelain, Brentjens and Rivière 2013, Abate-Daga and Davila 2016 and Jaspers and Brentjens 2017 [53-55].

In clinical studies, CAR T cell doses vary widely. Recent clinical trials with promising outcomes applied an intended dose range of $10^{6}-10^{7}$ cells/kg bodyweight (Sauter et al. 2014, Park et al. 2013, 2015, Schuster et al. 2015a, Popplewell et al. 2015, Ref. Table 2). Lee et al. (2015) [56] reported the clinical outcomes of two ALL patients that received a lower dose than planned. Patient 2 received $0.03 \times 10^{6}$ CAR T cells $/ \mathrm{kg}$ bodyweight and Patient 5 received $0.48 \times 10^{6}$ CAR T cells $/ \mathrm{kg}$ bodyweight instead of 1-3 $\times 10^{6} \mathrm{CAR}$ T cells/kg bodyweight. Patient 2 achieved stable disease and patient 5 achieved complete response that was minimum residual disease negative. Interestingly, the numbers of blood circulating CAR T cells in patients 2 and 5 at the day of evaluation were not significantly different from patients receiving the correct dosage. Thus, infusion of a lower than anticipated CAR T cell dose can be therapeutically effective, as long as sufficient expansion is seen after infusion.

\section{CAR T cell therapy quality assurance and control (QA/QC)}

Current published protocols adhere to guidelines of current good manufacturing practice (cGMP) on testing of safety, purity and potency $[14,15,57]$. Release criteria with respect to safety are sterility and the absence of replication competent viruses (in case of virally transduced cells). The presence of replication competent retro- or lentivirus is usually tested with a cell-based assay or a quantitative 
polymerase chain reaction (qPCR) assay $[14,58]$. In the United States Code of Federal Regulation (CFR) on "General Biological Product Standards" (21 CFR 610, 2 January 2018), the test methods for sterility are specified as either culture or non-culture based. One culture based method is based on the observation of growth of viable microorganisms after inoculating culture media with test material over several days $[15,57]$. Gram staining was used as a non-culture method for in-process samples by Hollyman et al. 2009 [14]. All implemented sterility tests have to be validated for the product they are used for. As cell and gene therapy is a rapidly evolving field, it is mandatory for drug developers to track the constant evolution of regulatory requirements.

Ideally, the product has a high purity. Enrichment or depletion of specific cell types or subsets can ensure a starting material with higher purity (see section 'Enrichment and depletion'). It can also be beneficial to test for contaminating cell populations, e.g. NK cells [15]. Other impurities are endotoxins, mycoplasma or residuals of the process, e.g. activating beads that might cause harm e.g. by being capable of activating endogenous T cells if transferred into the patient [14].

The product needs to be effective which is typically tested indirectly by assessment of transduction efficiency or by in vitro cytotoxicity tests. The CAR T vector copy number can be determined in process and be a measure of transduction efficiency [14]. However, the copy number does not necessarily reflect the level of CAR expression. The number of CAR positive cells can be determined by immunophenotyping of the CAR T cells at the end of production. For detection of the CAR, researchers introduced a tag into the transgene or CAR-specific mAbs were developed $[14,59]$. Some centres perform cytotoxicity assays in vitro, e.g. a chromium release assay. These consume time after the end of production and valuable cells. Singh et al. (2013) [15] used more than $0.5 \times 10^{6} \mathrm{~T}$ cells for a chromium release assay for a single product. Although methods are available to test potency of the T cells, no standardised method is used, making it difficult to compare CAR T cell potency across studies or platforms. To date, potency assays are one of the main challenges in CAR T cell product characterisation during QC. This is mainly due to the complexity of the mode of action of CAR T cell therapies and the lack of standardised methods [60].

\section{Manufacturing - A future perspective}

Batch production of monoclonal antibodies at commercial scale results in several thousand doses of mAbs [61]. This scale has not yet been considered in cell therapy. Currently, autologous small-scale processes for haematological malignancies dominate the field. Although some allogeneic CAR T cell therapy products have entered the clinics $[27,62]$, they have a number of safety concerns regarding the potential development of a graft-versus-host-disease (GvHD) [63]. Allogeneic therapies have, so far, been less efficacious than autologous therapies [64] and strategies to mediate the risk of a GvHD, 
such as inactivation of the TCR $\alpha$ and $\beta$ chain by genome editing, are currently under evaluation $[65,66]$.

Acute lymphoblastic leukaemia (ALL) is the target of the first-ever approved CAR T cell therapy Kymriah and the disease most treated in clinical trials (440 of 1000 patients) even though it accounts for less than $0.4 \%$ of all cancer diagnoses in USA (2015), UK (2013) and Germany (2012) (National Cancer Institute, Cancer Research UK, Robert-Koch-Institut Germany, Ref. Table 2). However, if cellular therapies for the 'big' cancers like lung and pancreatic cancer prove to be successful in clinical trials, a large production scale has to be considered.

Producing thousands of autologous products with individual processes is a new challenge that has to be faced in pharmaceutical production. Increasing the number of individual processes for personalised products is frequently termed scaling-out. Automated cell therapy manufacturing devices can enable manufacturing of a large number of personalised CAR T cell therapies. Mock et al. (2016) [67] used the CliniMACS Prodigy, an automated cell therapy production platform, for the generation of clinically relevant numbers of CD19-CAR T cells. They showed that the man hours needed for manufacturing can be greatly decreased with this system compared to a production process with the rocking motion bioreactor. The economic, infrastructural and regulatory feasibility of distributed manufacturing in hospitals in comparison to a centralised production model has to be evaluated.

\section{Conclusion}

Cell and gene therapies, particularly CAR-T cells, are an exciting new class of therapeutic offering potential cures to a number of diseases. Unfortunately, there are a number of concerns regarding costly and highly variable manufacturing processes. Here we have undertaken a systematic analysis of CAR-T clinical trials covering 1000 patients. Whilst there is a common set of processing steps, further scrutiny uncovered three dominant process routes and a wide range of process scales, associated with uncertainty over dose size. To date the majority of clinical trials have applied off the shelf processing equipment however there are major concerns regarding their ability to minimise run-to-run variability and production costs. The future trend will be towards a new breed of technology offering automation and integrated closed manufacturing solutions leading the field towards low cost manufacturing processes.

\section{Acknowledgements}

Partly, manufacturing process data was retrieved through correspondence with Jae H. Park and Craig Sauter (Memorial Sloan Kettering Cancer Center, New York NY, USA), Leslie Popplewell and Xiuli Wang (City of Hope Cancer Center, Duarte CA, USA), Partow Kebriaei and Harjeet Singh (University of 
Texas MD Anderson Cancer Center, Houston TX, USA), James N. Kochenderfer (Institute Center for Cancer Research at the National Cancer Institute, Bethesda MD, USA), Carlos A. Ramos (Center for Cell and Gene Therapy at the Baylor College of Medicine, Houston TX, USA) and David L. Porter (University of Pennsylvania, Philadelphia PA, USA). We wish to express our gratitude for the complementation of the gathered data.

Figures and tables

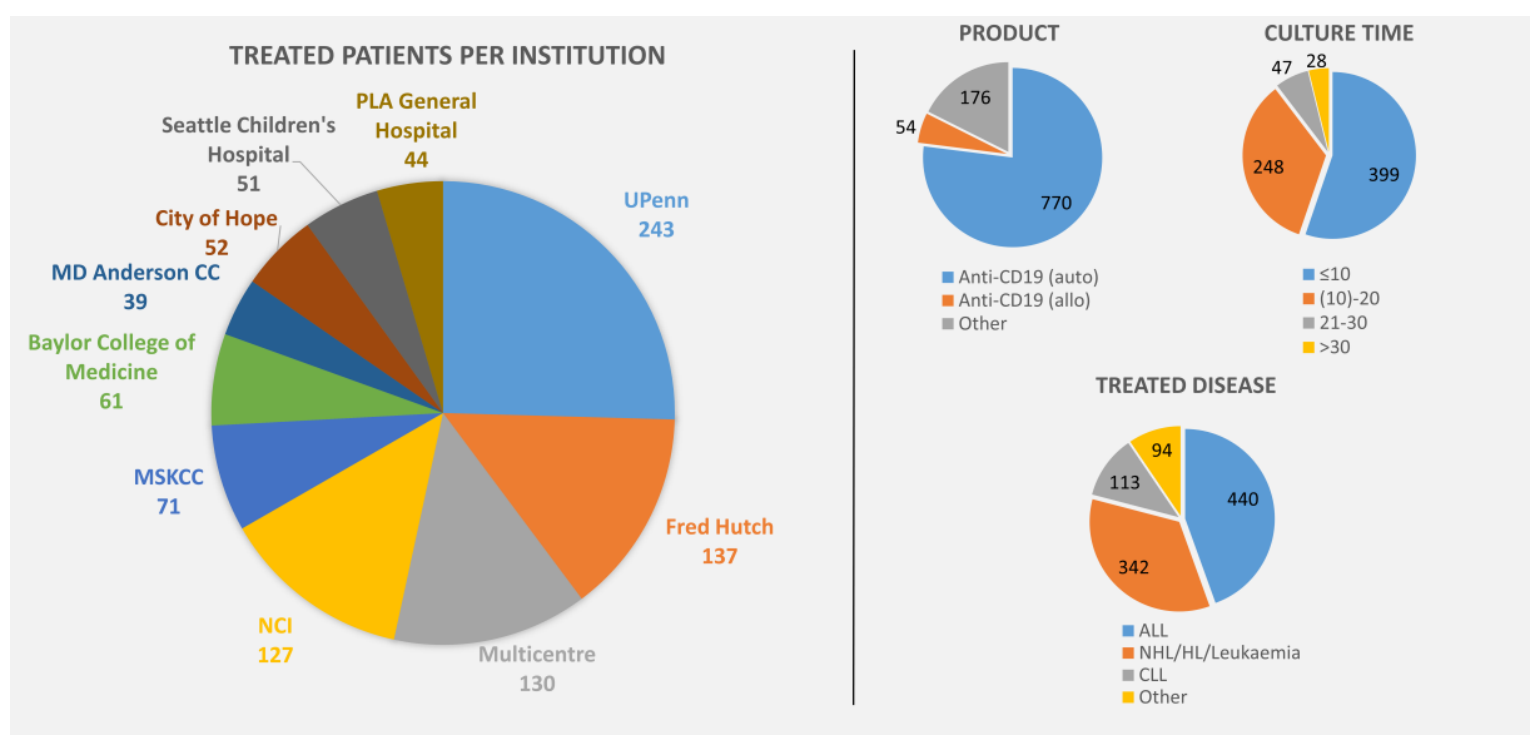

Figure 1: Characteristics of current CAR T cell treatments and products: a) Treated patients per institution University of Pennsylvania treated most of the patients to date; b) Target and origin of cells - Products are mainly autologous anti-CD19 CAR T cells; c) Culture time during manufacturing of CAR T cells - most products are manufactured in <20 days; d) Treated disease - Hematologic malignancies (ALL especially) are mainly treated; Abbreviations: Fred Hutch: Fred Hutchinson Cancer Research Center; MSKCC: Memorial Sloan Kettering Cancer Center; UPenn: University of Pennsylvania; MD Anderson CC: MD Anderson Cancer Center; PLA General Hospital: Chinese People's Liberation Army General Hospital; CLL: Chronic lymphocytic leukaemia; ALL: Acute lymphoblastic lymphoma; NHL: Non-Hodgkin lymphoma; HL: Hodgkin lymphoma.

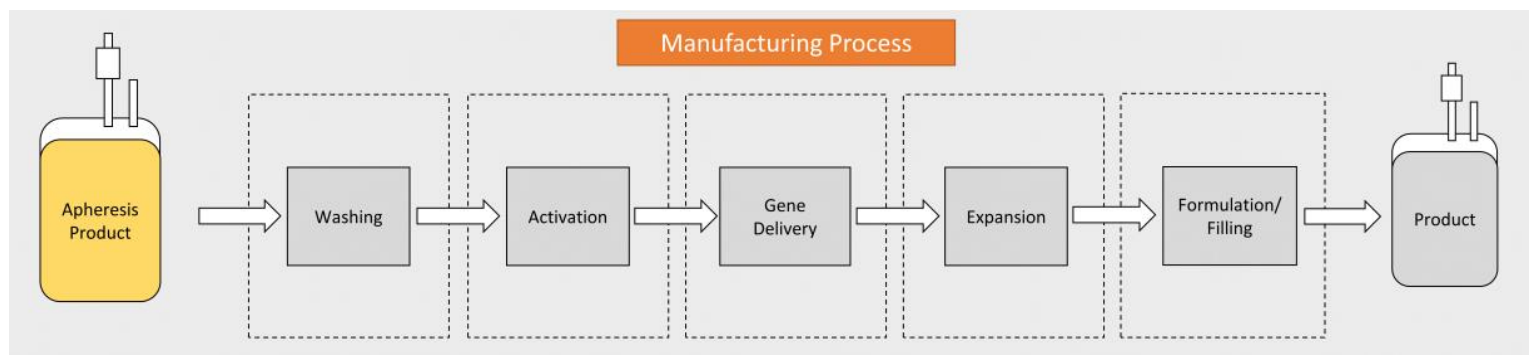

Figure 2: Flow scheme of the CAR T cell manufacturing process: The apheresis product is washed to remove anti-coagulants added during leukapheresis and then activated by stimulation through $\mathrm{T}$ cell activation pathways in cell culture media. Soluble monoclonal antibodies, coated magnetic beads or artificial antigen 
presenting cells are frequently used for activation. The CAR transgene is delivered into the cell by lenti- or retroviral and non-viral methods such as transposon/transposase systems. The cells are then expanded in static or dynamic culture vessels or devices to the required cell numbers. Finally, cell numbers and the media composition are adjusted according to the formulation (if the product is frozen, cryopreservation media are required) and then the product is transferred to a suitable container for delivery or freezing. Dashed lines represent system borders or the physical barrier of the vessels in which the process steps are carried out; arrows represent transfer steps.

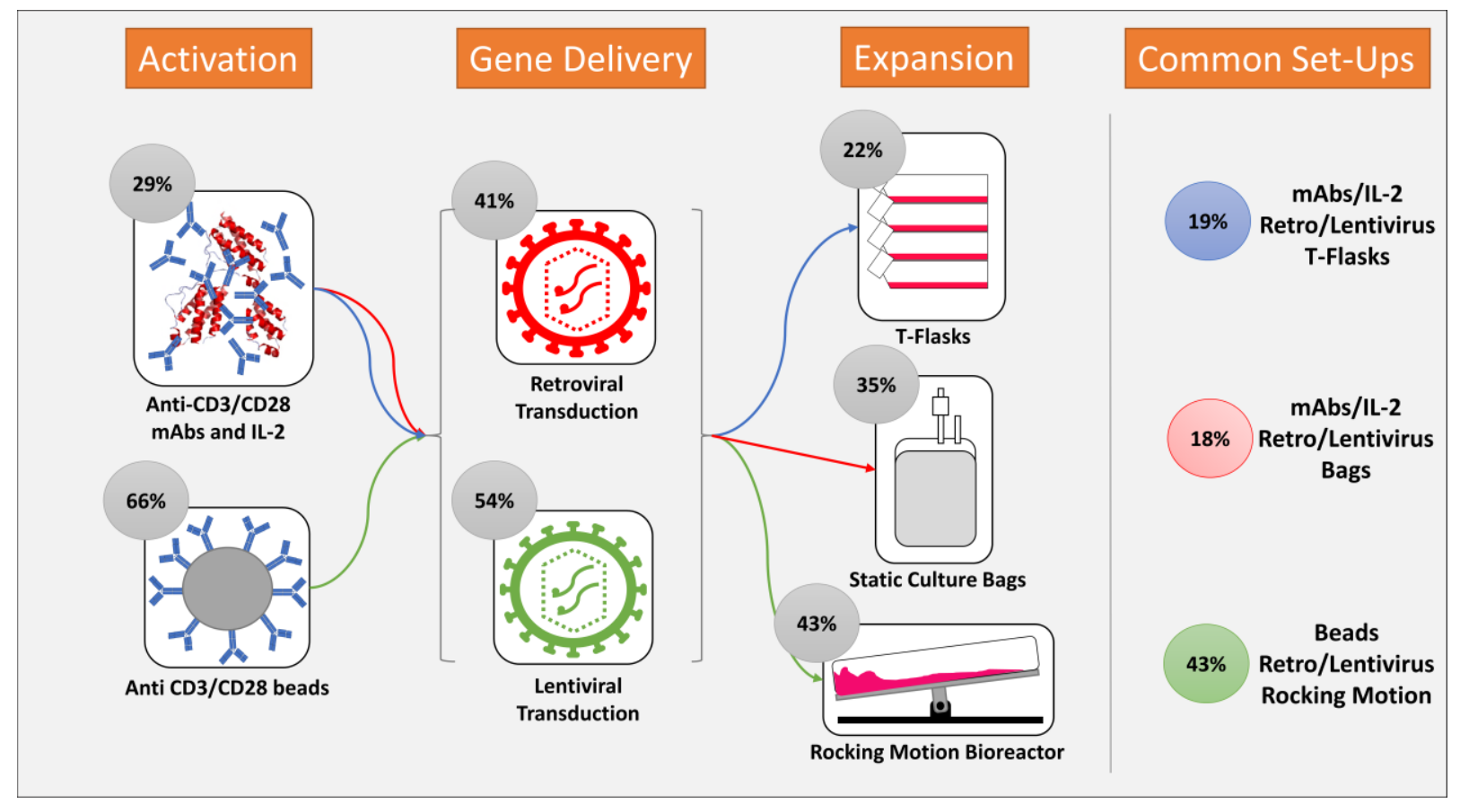

Figure 3: Current CAR T cell manufacturing routes. Frequency of technologies used for activation, gene delivery and expansion (grey circles) expressed as a percentage of evaluable products (Activation: 952/1000 products; gene delivery: 977/1000 products; expansion: 679/1000 products). The frequency of combinations (indicated by coloured arrows; coloured circles) again expressed as a percentage of evaluable products (429/679 products). 
Table 1: Clinical CAR T cell therapy trials with published manufacturing process data (2002-September 2017)

\begin{tabular}{|c|c|c|c|c|c|c|c|c|c|c|c|c|c|c|c|}
\hline Ref & Author & Year & $\begin{array}{l}\text { Institution } \\
\text { (associated } \\
\text { company) }\end{array}$ & $\begin{array}{l}\text { CAR- Product (Product } \\
\text { specification or name) }\end{array}$ & $\begin{array}{l}\text { CAR } \\
\text { Generation }\end{array}$ & Expansion & Activation & Gene Delivery & $\begin{array}{l}\text { Culture } \\
\text { Time } \\
\text { [days] }\end{array}$ & $\begin{array}{l}\text { References } \\
\text { for } \\
\text { Manufacturing } \\
\text { Data }\end{array}$ & $\begin{array}{l}\text { Disease } \\
\text { (No. of Pts.) }\end{array}$ & $\begin{array}{l}\text { Patients } \\
\text { Treated }\end{array}$ & Clinical Trail No & Phase & $\begin{array}{l}\text { Initiation of } \\
\text { Study (year- } \\
\text { month) }\end{array}$ \\
\hline [28] & Deeks & 2002 & $\begin{array}{l}\text { University of } \\
\text { California }\end{array}$ & anti-HIVgp120 & 1st & $\mathrm{N} / \mathrm{s}$ & anti-CD3/CD28 beads & retroviral & $10-17$ & [68] & HIV (20) & 20 & $\mathrm{~N} / \mathrm{s}$ & II & $\leq 2002$ \\
\hline [10] & Jensen & 2010 & City of Hope & anti-CD19 & 1st & $\begin{array}{l}\text { flasks and/ or } \\
\text { plates }\end{array}$ & $\begin{array}{l}\text { OKT3, IL-2, irr. all. } \\
\text { PBMCs, LCL }\end{array}$ & $\begin{array}{l}\text { plasmid, } \\
\text { electroporation, } \\
\text { Hygromycin selection }\end{array}$ & 55 & & $\mathrm{FL}(2)$ & 2 & BB-IND-11411//RB 01160 & 1 & $\leq 2010$ \\
\hline [10] & Jensen & 2010 & City of Hope & anti-CD20 & 1st & $\begin{array}{l}\text { flasks and/or } \\
\text { plates }\end{array}$ & $\begin{array}{l}\text { OKT3, IL-2, irr. all. } \\
\text { PBMCS, LCL }\end{array}$ & $\begin{array}{l}\text { plasmid, } \\
\text { electroporation, G418 } \\
\text { selection }\end{array}$ & 62 & & DLBCL (2) & 2 & BB-IND-8513//RB 98142 and & 1 & $\leq 2010$ \\
\hline [40] & Park & 2007 & Seattle Children's & anti-CD171 & 1st & $\begin{array}{l}\text { flasks and/or } \\
\text { plates }\end{array}$ & $\begin{array}{l}\text { OKT3, IL-2, irr. all. } \\
\text { PBMCS, LCL }\end{array}$ & $\begin{array}{l}\text { plasmid, } \\
\text { electroporation, } \\
\text { Hygromycin selection }\end{array}$ & $>42$ & [19] & NB (6) & 6 & $\mathrm{~N} / \mathrm{s}$ & 1 & - \\
\hline [9] & Till & 2008 & Fred Hutch & anti-CD20 & 1 st & $\begin{array}{l}\text { static culture } \\
\text { bags }\end{array}$ & $\begin{array}{l}\text { OKT3, IL-2, irr. all. } \\
\text { PBMCS, LCL }\end{array}$ & $\begin{array}{l}\text { plasmid, } \\
\text { electroporation, G418 } \\
\text { selection }\end{array}$ & 70-132 & & FL (7) & 7 & NCT00012207 & 1 & 2000-09 \\
\hline [69] & Louis & 2011 & $\begin{array}{l}\text { Baylor College of } \\
\text { Medicine }\end{array}$ & anti-GD2 & 1st & $\begin{array}{l}\text { flasks and/or } \\
\text { plates }\end{array}$ & ОКТз, LL-2 & retroviral & 15 & [70] & NB (19) & 19 & NCT00085930 & 1 & 2003-04 \\
\hline [71] & Junghans & 2016 & $\begin{array}{l}\text { Roger Williams } \\
\text { Medical Center }\end{array}$ & anti-PSMA & 1st & $\begin{array}{l}\text { flasks and/or } \\
\text { plates }\end{array}$ & Anti-CD3 & retroviral & 14 & & Prostate Cancer (6) & 6 & NCT01929239 & 1 & $2006-03$ \\
\hline$[A],[29]$ & $\begin{array}{l}\text { Brentjens, } \\
\text { Park, } \\
\text { Geyer }\end{array}$ & $\begin{array}{l}2011, \\
2012, \\
2016\end{array}$ & мSксC & anti-CD19 & 2nd: CD28 & $\begin{array}{l}\text { RM } \\
\text { bioreactor }\end{array}$ & anti-CD3/CD28 beads & retroviral & $11-19$ & [14] & CLL (11) & 11 & NCT00466531 & 1/II & 2007-03 \\
\hline [72] & Till & 2012 & Fred Hutch & anti-CD20 & $\begin{array}{l}\text { 3rd : } 4-1 \mathrm{BB} \\
+\mathrm{CD} 28\end{array}$ & $\begin{array}{l}\text { static culture } \\
\text { bags }\end{array}$ & $\begin{array}{l}\text { OKT3, IL-2, irr. all. } \\
\text { PBMCS, LCL }\end{array}$ & $\begin{array}{l}\text { plasmid, } \\
\text { electroporation, G418 } \\
\text { selection }\end{array}$ & $69+$ & [9] & $\begin{array}{l}\mathrm{MCL}(2) \\
\mathrm{FL}(1)\end{array}$ & 3 & NCT00621452 & 1 & 2007-08 \\
\hline [73] & Savoldo & 2011 & $\begin{array}{l}\text { Baylor College of } \\
\text { Medicine }\end{array}$ & anti-CD19 & $\begin{array}{l}\text { Both 1st } \\
\text { and 2nd } \\
\text { (CD28) }\end{array}$ & $\begin{array}{l}\text { flasks and/or } \\
\text { plates }\end{array}$ & $\begin{array}{l}\text { immobilised OKT3, LL- } \\
2\end{array}$ & retroviral & $\mathrm{N} / \mathrm{s}$ & & $\begin{array}{l}\text { DLBCL(5) } \\
\text { SLL(1) }\end{array}$ & 6 & NCT00586391 & & \\
\hline [74] & Kochenderfer & 2010 & $\begin{array}{l}\text { National Cancer } \\
\text { Institute }\end{array}$ & anti-CD19 & 2nd: CD28 & $\begin{array}{l}\text { flasks and/or } \\
\text { plates }\end{array}$ & $\begin{array}{l}\text { OKT3, IL-2, autologous } \\
\text { PBMCs }\end{array}$ & retroviral & 14 & [75] & $\mathrm{FL}(1)$ & 1 & NCT00924326 & 1 & 2009-02 \\
\hline [76] & Kochenderfer & 2012 & $\begin{array}{l}\text { National Cancer } \\
\text { Institute }\end{array}$ & anti-CD19 & 2nd: CD28 & $\begin{array}{l}\text { flasks and/or } \\
\text { plates }\end{array}$ & $\begin{array}{l}\text { OKT3, IL-2, irr. all. } \\
\text { PBMCS }\end{array}$ & retroviral & 24 & [75] & $\begin{array}{l}\text { CLL (4) } \\
\text { FL (3) } \\
\text { SMZL (1) }\end{array}$ & 8 & NCT00924326 & 1 & 2009-02 \\
\hline$[A]$ & Kochenderfer & 2014 & $\begin{array}{l}\begin{array}{l}\text { National Cancer } \\
\text { Institute }\end{array}\end{array}$ & anti-CD19 & 2nd: CD28 & $\begin{array}{l}\text { flasks and/or } \\
\text { plates }\end{array}$ & $\begin{array}{l}\text { OKT3, IL-2, irr. all. } \\
\text { PBMCS }\end{array}$ & retroviral & 10 & [76] & $\begin{array}{l}\text { DLBCL }(8) \\
\text { FL(1) }\end{array}$ & 9 & NCT00924326 & 1 & 2009-02 \\
\hline [77] & Kochenderfer & 2015 & $\begin{array}{l}\begin{array}{l}\text { National Cancer } \\
\text { Institute }\end{array}\end{array}$ & anti-CD19 & 2nd: CD28 & $\begin{array}{l}\text { flasks and/or } \\
\text { plates }\end{array}$ & ОКТз, LL-2 & retroviral & $6-10$ & $\begin{array}{l}{[76],} \\
\text { Kochenderfer } \\
\text { et al. } 2013 \text { [A] }\end{array}$ & $\begin{array}{l}\text { CLL (4) } \\
\text { SMZL (1) } \\
\text { PBMCL (4) } \\
\text { DLBCL (5) } \\
\text { low grade NHL (1) }\end{array}$ & 15 & NCT00924326 & 1 & 2009-02 \\
\hline [27] & Cruz & 2013 & $\begin{array}{l}\text { Baylor College of } \\
\text { Medicine }\end{array}$ & $\begin{array}{l}\text { anti-CD19 } \\
\text { (Virusspecific, } \\
\text { allogeneic) }\end{array}$ & 2nd: CD28 & $\begin{array}{l}\text { flasks and/or } \\
\text { plates }\end{array}$ & $\mathrm{IL}-2, \mathrm{LCL}$ as APCS & retroviral & $>35-42$ & & $\begin{array}{l}\text { CLL (4) } \\
\text { ALL (4) }\end{array}$ & 8 & NCT00840853 & 1 & 2009-04 \\
\hline$[\mathrm{A}]$ & $\begin{array}{l}\text { Ramos, } \\
\text { Ramos }\end{array}$ & $\begin{array}{l}2013, \\
2016\end{array}$ & $\begin{array}{l}\text { Baylor College of } \\
\text { Medicine }\end{array}$ & anti-k & 2nd: CD28 & $\begin{array}{l}\text { flasks and/or } \\
\text { plates }\end{array}$ & $\begin{array}{l}\text { immobilised OKT3 or } \\
\text { CD3/CD28 monoclonal } \\
\text { antibodies + IL-2 }\end{array}$ & retroviral & $14-22$ & & $\begin{array}{l}\mathrm{NHL}(5) \\
\mathrm{MM}(3) \\
\mathrm{CLL}(2)\end{array}$ & 10 & NCT00881920 & 1 & 2009-07 \\
\hline $\begin{array}{r}{[A],} \\
{[17,52,78]}\end{array}$ & $\begin{array}{l}\text { Porter, } \\
\text { Kalos, } \\
\text { Porter, } \\
\text { Porter }\end{array}$ & $\begin{array}{l}2011, \\
2011, \\
2013, \\
2015\end{array}$ & $\begin{array}{l}\text { UPenn } \\
\text { (Novartis) }\end{array}$ & $\begin{array}{l}\text { anti-CD19 } \\
\text { (CTLO19) }\end{array}$ & 2nd: $4-1 B B$ & $\begin{array}{l}\mathrm{RM} \\
\text { bioreactor }\end{array}$ & anti-CD3/CD28 beads & lentiviral & 8-12 & & CLL (14) & 14 & NCT01029366 & 1 & 2009-07 \\
\hline [79] & Ritchie & 2013 & UMelbourne & anti-LeY & 2nd: CD28 & $\begin{array}{l}\text { flasks and/or } \\
\text { plates }\end{array}$ & ОКтз, LL-2 & retroviral & 12 & & AML (4) & 4 & CTX 08-0002 & 1 & $\mathrm{~N} / \mathrm{s}$ \\
\hline $\begin{array}{r}{[A],} \\
{[29,80,81]}\end{array}$ & $\begin{array}{l}\text { Brentjens, } \\
\text { Brentjens, } \\
\text { Davila, } \\
\text { Park, } \\
\text { Park }\end{array}$ & $\begin{array}{l}2011, \\
2013, \\
2014, \\
2014, \\
2015\end{array}$ & $\begin{array}{l}\text { MSKCC } \\
\text { (Juno) }\end{array}$ & $\begin{array}{l}\text { anti-CD19 } \\
\text { (JCAR015) }\end{array}$ & 2nd: CD28 & $\begin{array}{l}\mathrm{RM} \\
\text { bioreactor }\end{array}$ & anti-CD3/CD28 beads & retroviral & $11-19$ & [14] & ALL (44) & 44 & NCT01044069 & 1 & 2010-01 \\
\hline$[A],[82]$ & $\begin{array}{l}\text { Kochenderfer, } \\
\text { Brudno }\end{array}$ & $\begin{array}{l}2013, \\
2016\end{array}$ & $\begin{array}{l}\text { National Cancer } \\
\text { Institute }\end{array}$ & $\begin{array}{l}\text { anti-CD19 } \\
\text { (allogeneic) }\end{array}$ & 2nd: CD28 & $\begin{array}{l}\text { flasks and/or } \\
\text { plates }\end{array}$ & ОКT3, LL-2 & retroviral & 8 & & $\begin{array}{l}\text { ALL (5) } \\
\text { CLL) (5) } \\
\text { DLCLL) } \\
\text { MCL (5) }\end{array}$ & 20 & NCT01087294 & 1 & 2010-02 \\
\hline$[A]$ & Ramos & 2016 & $\begin{array}{l}\text { Baylor College of } \\
\text { Medicine }\end{array}$ & anti-CD30 & 2nd: CD28 & $\mathrm{N} / \mathrm{s}$ & $\mathrm{N} / \mathrm{s}$ & retroviral & $12-18$ & & $\begin{array}{l}\text { HLL (7) } \\
\text { ALCL (2) }\end{array}$ & 9 & NCT01192464 & 1 & 2010-08 \\
\hline
\end{tabular}


Review: A guide to manufacturing CAR T cell therapies

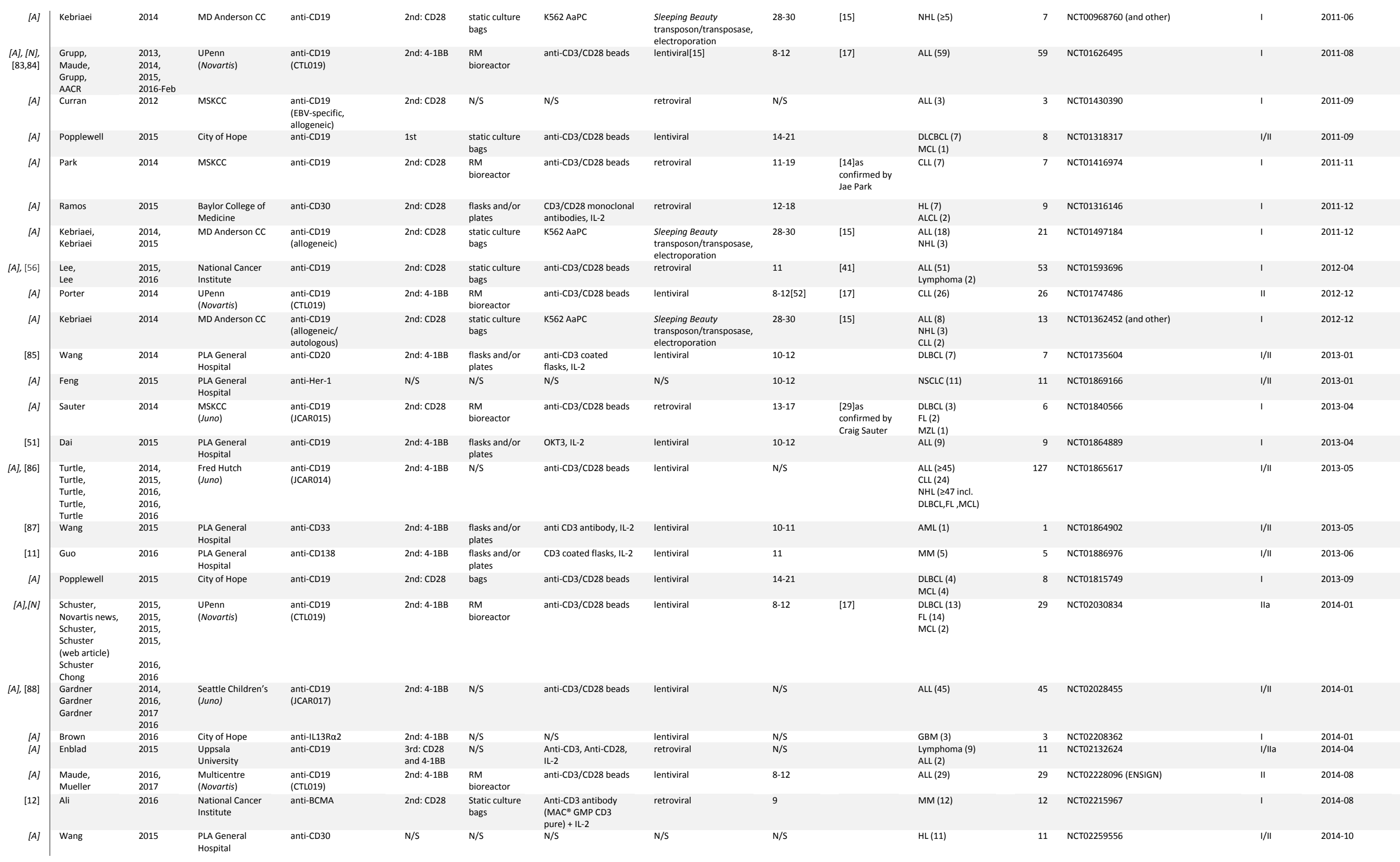




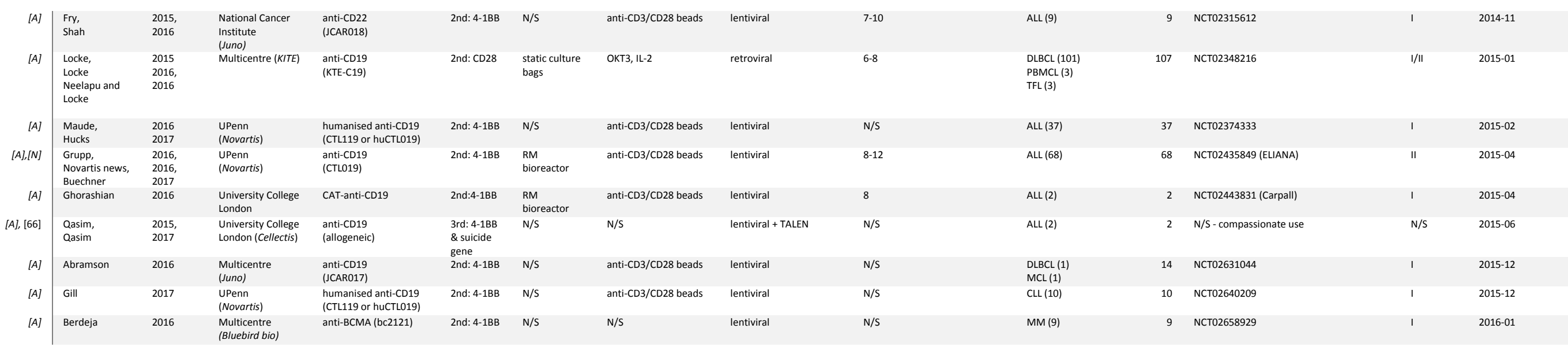

Manufacturing process data and culture time originates from primary reports, references in the reports and communication with conductors of the trials. Reports covered are from 2002 until September 2017. [A] marks Conference abstracts, [N] marks news, references shown in Table 2; Abbreviations: Fred Hutch: Fred Hutchinson Cancer Research Center; MSKCC: Memorial Sloan Kettering Cancer Center; UPenn: University of Pennsylvania; UMelbourne: University of Melbourne; MD Anderson CC: MD Anderson Cancer Center; PLA General Hospital: Chinese People's Liberation Army General Hospital; AACR: American Association for Cancer Research; HIV: Human immune deficiency virus; (T)FL: (Transformed) follicular lymphoma; DLBCL: Diffuse large B cell lymphoma; NB: Neuroblastoma; CLL: Chronic lymphocytic leukaemia; MCL: Mantle cell lymphoma; ALL: Acute lymphoblastic lymphoma; NHL: Non-Hodgkin lymphoma; MM: Multiple myeloma; AML: Acute myeloid leukaemia; HL: Hodgkin lymphoma; SLL: Small lymphocytic lymphoma; SMZL: Splenic marginal zone lymphoma; PBMCL: Primary mediastinal large B cell lymphoma; GMB: Glioblastoma; ALCL: Anaplastic large cell lymphoma; EBV: Epstein-Barr virus; RM: Rocking motion, TALEN: Transcription activator-like effector nuclease. 
Table 2: Conference abstracts and news referenced in Table 1.

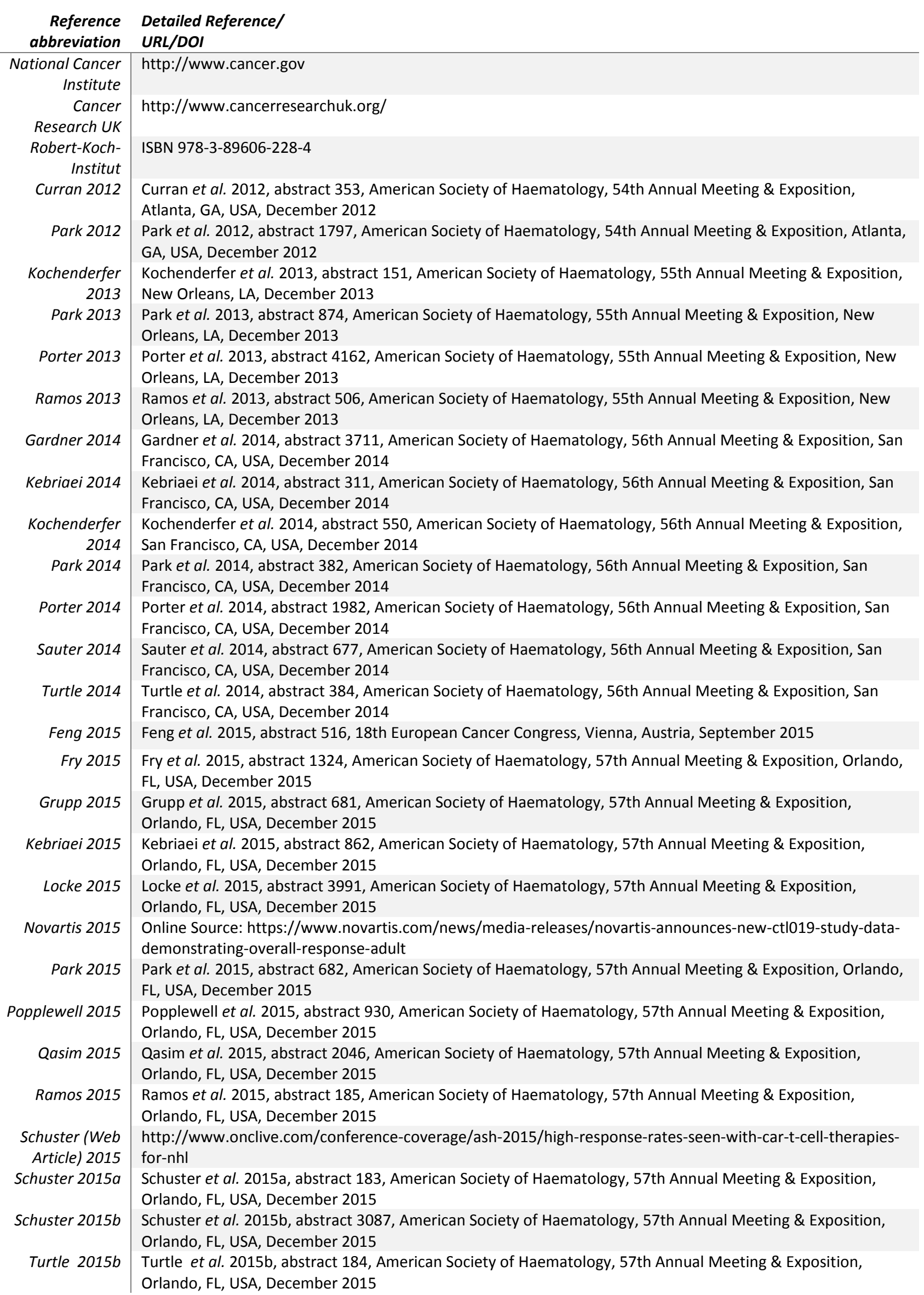


Turtle 2015a $\mid$ Turtle et al. 2015a, abstract 3773, American Society of Haematology, 57th Annual Meeting \& Exposition, Orlando, FL, USA, December 2015

Wang 2015 Wang et al. 2015, abstract S12, The Lancet - CAMS Health Summit, Beijing, China, October 2015

Abramson 2016

Berdeja 2016

Brown 2016

Cancer

Discovery 2016

Chong 2016

Enblad 2016

Gardner 2016

Geyer 2016

Ghorashian

2016

Grupp 2016

Lee 2016

Locke 2016

Neelapu and

Locke 2016

Maude $2016 a$

Maude $2016 b$

Novartis news

2016

Ramos 2016

Schuster 2016

Shah 2016

Turtle 2016a

Turtle 2016b

Hucks 2017

Gill 2017

Mueller 2017

Buechner 2017 Buechner et al. 2017, abstract ALL-152, Society of Hematologic Oncology, 2017 Annual Meeting, Houston, TX, Abramson et al. 2016, abstract 4192, American Society of Haematology, 58th Annual Meeting \& Exposition, San Diego, CA, USA, December 2016 Berdeja et al. 2016, abstract 14LBA, EORTC-NCI-AACR Symposium on Molecular Targets and Cancer Therapeutics, Munich, Germany, December 2016 Brown et al. 2016, abstract 247, American Society of Gene \& Cell Therapy 19th Annual Meeting, Washington, D.C., USA, May 2016 doi: 10.1158/2159-8290.CD-NB2015-178

Chong et al. 2016, abstract 1100, American Society of Haematology, 58th Annual Meeting \& Exposition, San Diego, CA, USA, December 2016

Enblad et al. 2016, abstract 1534, American Society of Haematology, 57th Annual Meeting \& Exposition, Orlando, FL, USA, December 2015

Gardner et al. 2016, abstract 614, American Society of Haematology, 58th Annual Meeting \& Exposition, San Diego, CA, USA, December 2016

Geyer et al. 2016, abstract 642, American Society of Haematology, 58th Annual Meeting \& Exposition, San Diego, CA, USA, December 2016

Ghorashian et al. 2016, abstract 4026, American Society of Haematology, 58th Annual Meeting \& Exposition, San Diego, CA, USA, December 2016

Grupp et al. 2016, abstract 221, American Society of Haematology, 58th Annual Meeting \& Exposition, San Diego, CA, USA, December 2016

Lee et al. 2016, abstract 218, American Society of Haematology, 58th Annual Meeting \& Exposition, San Diego, CA, USA, December 2016

Locke et al. 2016, abstract 998, American Society of Haematology, 58th Annual Meeting \& Exposition, San Diego, CA, USA, December 2016

Neelapu and Locke et al. 2016, abstract LBA-6, American Society of Haematology, 58th Annual Meeting \& Exposition, San Diego, CA, USA, December 2016

Maude et al. 2016a, abstract 217, American Society of Haematology, 58th Annual Meeting \& Exposition, San Diego, CA, USA, December 2016

Maude et al. 2016b, abstract 681, American Society of Haematology, 58th Annual Meeting \& Exposition, San Diego, CA, USA, December 2016

https://www.novartis.com/news/media-releases/novartis-presents-results-first-global-registration-trialctl019-pediatric-and

Ramos et al. 2016, abstract 177, 2016 BMT Tandem Meetings, Honolulu, HI, USA, February 2016

Schuster et al. 2016, abstract 3026, American Society of Haematology, 58th Annual Meeting \& Exposition, San Diego, CA, USA, December 2016

Shah et al. 2016, abstract 650, American Society of Haematology, 58th Annual Meeting \& Exposition, San Diego, CA, USA, December 2016

Turtle et al. 2016a, abstract 56, American Society of Haematology, 58th Annual Meeting \& Exposition, San Diego, CA, USA, December 2016

Turtle et al. 2016b, abstract 1852, American Society of Haematology, 58th Annual Meeting \& Exposition, San Diego, CA, USA, December 2016

Hucks et al. 2017, abstract 7, International Society for Cellular Therapy, 2017 Annual Meeting, London, UK, May 2017

Gill et al. 2017, abstract 7509, American Society of Clinical Oncology, 2017 Annual Meeting, Chicago, IL, USA, June 2017 USA, September 2017

Mueller et al. 2017, abstract ALL-152, Society of Hematologic Oncology, 2017 Annual Meeting, Houston, TX, USA, September 2017 
Review: A guide to manufacturing CAR T cell therapies

\section{References}

1. Maude S, Barrett DM: Current status of chimeric antigen receptor therapy for haematological malignancies. Br. J. Haematol. 2015, 172:11-22.

2. Gross G, Waks T, Eshhar Z: Expression of immunoglobulin-T-cell receptor chimeric molecules as functional receptors with antibody-type specificity. Proc. Natl. Acad. Sci. U. S. A. $1989,86: 10024-10028$.

Walker A, Johnson R: Commercialization of cellular immunotherapies for cancer. Biochem. Soc. Trans. 2016, 44:329-332. Vera JF, Brenner $U$, Gerdemann U, Ngo MC, Sili U, Liu H, Wilson J, Dotti $G$, Heslop HE, Leen AM, et al. Accelerated production of antigen-specific $T$ cells for preclinical and clinical applications using gas-permeable rapid expansion cultureware (G-Rex). J. Immunother. 2010, 33:305-15. Kaiser AD, Assenmacher M, Schröder B, Meyer M, Orentas R, Bethke U, Dropulic B: Towards a commercial process for the manufacture of genetically modified T cells for therapy. Cancer Gene Ther. 2015, 22:72-8.

Engstad CS, Gutteberg TJ, Osterud B: Modulation of blood cell activation by four commonly used anticoagulants. Thromb. Haemost. 1997, 77:690-696.

McFarland DC, Zhang C, Thomas HC, T L R: Confounding effects of platelets on flow cytometric analysis and cell-sorting experiments using blood-derived cells. Cytometry A 2006, 69:86-94

Fesnak A, Lin C, Siegel DL, Maus M V: CAR-T cell therapies from the transfusion medicine perspective. Transfus. Med. Rev. 2016, 30:139-145.

Till BG, Jensen MC, Wang J, Chen EY, Wood BL, Greisman H a, Oian X, James SE, Raubitschek A, Forman SJ, et al. Adoptive immunotherapy for indolent non-Hodgkin lymphoma and mantle cell lymphoma using genetically modified autologous Adoptive immunotherapy for indolent non-Hodgkin lymphoma and mantle cell lymphoma using genetically modified autologous CD20-specific T. 2008, 112:2261-2271.

Jensen MC, Popplewell L, Cooper L, DiGiusto D, Kalos M, Ostberg JR, Forman SJ: Antitransgene rejection responses contribute to attenuated persistence of adoptively transferred CD20/CD19-specific chimeric antigen receptor redirected T cells in humans. Biol. Blood Marrow Transplant. 2010, 16:1245-1256.

Guo B, Chen M, Han Q, Hui F, Dai H, Zhang W, Zhang Y, Wang Y, Zhu H, Han W: CD138-directed adoptive immunotherapy of Chimeric Antigen Receptor (CAR)-modified T cells for Multiple Myeloma. J. Cell. Immunother. 2015, 2:28-35.

Ali SA, Shi V, Maric I, Wang M, Stroncek DF, Rose JJ, Brudno JN, Stetler-Stevenson M, Feldman SA, Hansen BG, et al.: T cells expressing an anti-B-cell maturation antigen chimeric antigen receptor cause remissions of multiple myeloma. Blood 2016, 128:1688 LP-1700.

13. Levine BL: Performance-enhancing drugs: design and production of redirected chimeric antigen receptor (CAR) T cells. Cancer Gene Ther. 2015, 22:79-84.

14. Hollyman D, Stefanski J, Przybylowski M, Bartido S, Borquez-Ojeda O, Taylor C, Yeh R, Capacio V, Olszewska M, Hosey J, et al.: Manufacturing validation of biologically

Hollyman D, Stefanski J, Przybylowski M, Bartido S, Borquez-Ojeda O, Taylor C, Yeh R, Capacio V, Olszewska M, Hosey J, et al.: Manufacturing validation of biologically
functional T cells targeted to CD19 antigen for autologous adoptive cell therapy. J. Immunother. 2009, 32:169-180.
Singh H, Figliola MJ, Dawson MJ, Olivares S, Zhang L, Yang G, Maiti S, Manuri P, Senyukov V, Jena B, et al.: Manufacture of Clinical-Grade CD19-Specific T Cells Stably Expressing Chimeric Antigen Receptor Using Sleeping Beauty System and Artificial Antigen Presenting Cells. PLoS One 2013, 8:1-11.

- Singh H, Moyes JS, Huls MH, Cooper UN: Manufacture of T cells using the Sleeping Beauty system to enforce expression of a CD19-specific chimeric antigen receptor Cancer Gene Ther. 2015, 22:95-100.

Here the authors describe how they have used the transposon-mediated gene-integration method, Sleeping Beauty, to produce a CD19 CAR T-cell. Most importantly, they describe how this method has been successfully integrated into a cGMP process, producing the CD19 CAR-T cell product used in clinical trials associated with the MD Anderson Cancer.

Kalos M, Levine BL, Porter DL, Katz S, Grupp SA, Bagg A, June CH: T cells with chimeric antigen receptors have potent antitumor effects and can establish memory in patients with advanced leukemia. Sci. Transl. Med. 2011, 3:95ra73.

Chen L, Flies DB: Molecular mechanisms of T cell co-stimulation and co-inhibition. Nat. Rev. Immunol. 2013, 13:227-242.

Jensen M: Human T Lymphocyte Genetic Modification with Naked DNA. Mol. Ther. 2000, 1:49-55.

Riddell SR, Greenberg PD: The use of anti-CD3 and anti-CD28 monoclonal antibodies to clone and expand human antigen-specific T cells. J. Immunol. Methods 1990, 128:189-201.

Gattinoni L, Lugli E, Ji Y, Pos Z, Paulos CM, Quigley MF, Almeida JR, Gostick E, Yu Z, Carpenito C, et al.: A human memory T cell subset with stem cell-like properties. Nat Med 2011, 17:1290-1297.

22. Wherry EJ: T cell exhaustion. Nat Immunol 2011, 12:492-499.

23. Barrett DM, Singh N, Liu X, Jiang S, June CH, Grupp SA, Zhao Y: Relation of clinical culture method to T-cell memory status and efficacy in xenograft models of adoptive Barrett DM, Singh N, Liu X, Jiang S, June CH, Grup immunotherapy. Cytotherapy 2014, 16:619-630.
in

.- Ghassemi S, Bedoya F, Nunez-Cruz S, June C, Melenhorst J, Milone M: Shortened T cell culture with IL-7 and IL-15 provides the most potent chimeric antigen receptor (CAR)-modified T cells for adoptive immunotherapy. J. Immunol. 2016, 196:214.23 LP-214.23.

In this paper, the authors compare the use of IL-2 to the use of IL-7 and IL-15 for activation and found the latter to enhance the survival of stem cell memory cells. Moreover, they found that a shorter culture time resulted in a more efficacious T cell product.

Casati A, Varghaei-Nahvi A, Feldman SA, Assenmacher M, Rosenberg SA, Dudley ME, Scheffold A: Clinical-scale selectio memory CD8+ T cells for adoptive cell therapy of cancer patients. Cancer Immunol. Immunother. 2013, 62:1563-1573. Kebriaei P, Huls H, Singh H, Olivares S, Figliola M, Maiti S, Shihuang S, Kumar PR, Jena B, Forget MA, et al.: Adoptive Therapy Using Sleeping Beauty Gene Transfer System and Artificial Antigen Presenting Cells to Manufacture T Cells Expressing CD19-Specific Chimeric Antigen Receptor. Blood 2014, 124:311. Cruz CRY, Micklethwaite KP, Savoldo B, Ramos CA, Lam S, Ku S, Diouf O, Liu E, Barrett AJ, Ito S, et al.: Infusion of donor-derived CD19-redirected virus-specific T cells for Bcell malignancies relapsed after allogeneic stem cell transplant : a phase 1 study. Blood 2013, 122:2965-2974.

Deeks S: A Phase II Randomized Study of HIV-Specific T-Cell Gene Therapy in Subjects with Undetectable Plasma Viremia on Combination Antiretroviral Therapy. Mol. Ther. 2002, 5:788-797.

Brentjens RJ, Rivière I, Park JH, Davila ML, Wang X, Stefanski J, Taylor C, Yeh R, Bartido S, Borquez-Ojeda O, et al.: Safety and persistence of adoptively transferred autologous CD19-targeted T cells in patients with relapsed or chemotherapy refractory B-cell leukemias. Blood 2011, 118:4817-4828.

Ghorashian S, Pule M, Amrolia P: CD19 chimeric antigen receptor T cell therapy for haematological malignancies. Br. J. Haematol. 2015, 169:463-478.

- Ramanayake S, Bilmon I, Bishop D, Dubosq MC, Blyth E, Clancy L, Gottlieb D, Micklethwaite K: Low-cost generation of Good Manufacturing Practice-grade CD19-specific chimeric antigen receptor-expressing T cells using piggyBac gene transfer and patient-derived materials. Cytotherapy 2015, 17:1251-1267.

The authors developed a simple and inexpensive CAR T cell production process using the novel transposon/transposase system piggyBac. Merten O-W, Hebben M, Bovolenta C: Production of lentiviral vectors. Mol. Ther. - Methods Clin. Dev. 2016, 3:16017.

33. - Sanber KS, Knight SB, Stephen SL, Bailey R, Escors D, Minshull J, Santilli G, Thrasher AJ, Collins MK, Takeuchi Y: Construction of stable packaging cell lines for clinical lentiviral vector production. Sci. Rep. 2015, 5:9021.

The authors describe a method for the production of a stable packaging cell line that is able to continuously produce lentiviral vectors.

Wang X, Rivière I: Manufacture of tumor- and virus-specific T lymphocytes for adoptive cell therapies. Cancer Gene Ther. 2015, 22:85-94.

Ivics Z, Hackett PB, Plasterk RH, Izsvák Z: Molecular Reconstruction of Sleeping Beauty, a Tc1-like Transposon from Fish, and Its Transposition in Human Cells. Cell 1997, 91:501-510.

Singh H, Figliola MJ, Dawson MJ, Huls H, Olivares S, Switzer K, Mi T, Maiti S, Kebriaei P, Lee DA, et al.: Reprogramming CD19-specific T cells with IL-21 signaling can improve adoptive immunotherapy of B-lineage malignancies. Cancer Res. 2011, 71:3516-3527.

Kebriaei P, Ciurea SO, Huls MH, Singh H, Olivares S, Su S, Figliola MJ, Kumar P, Jena B, Forget M-A, et al.: Pre-Emptive Donor Lymphocyte Infusion with CD19-Directed, CARModified T Cells Infused after Allogeneic Hematopoietic Cell Transplantation for Patients with Advanced CD19+ Malignancies. Blood 2015, 126:862.

Zhang C, Liu J, Zhong JF, Zhang X: Engineering CAR-T cells. Biomark. Res. 2017, 5:22.

Gogol-Döring A, Ammar I, Gupta S, Bunse M, Miskey C, Chen W, Uckert W, Schulz TF, Izsvák Z, Ivics Z: Genome-wide Profiling Reveals Remarkable Parallels Between Insertion Site Selection Properties of the MLV Retrovirus and the piggyBac Transposon in Primary Human CD4(+) T Cells. Mol. Ther. 2016, 24:592-606.

Park JR: Adoptive Transfer of Chimeric Antigen Receptor Re-directed Cytolytic T Lymphocyte Clones in Patients with Neuroblastoma. Mol. Ther. J. Am. Soc. Gene Ther. Park JR: Adoptive $2007,15: 825-833$

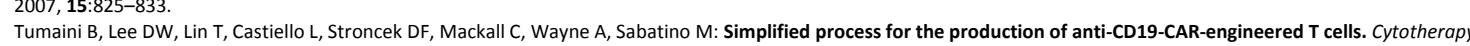

42. Janas M, Nunes C, Marenghi A, Sauvage V, Davis B, Bajaj A, Burns A: Perfusion's role in maintenance of high-density T-cell cultures. Bioprocess Int. 2015, 13:18-26.

43. Sadeghi A, Pauler L, Annerén C, Friberg A, Brandhorst D, Korsgren O, Tötterman TH: Large-scale bioreactor expansion of tumor-infiltrating lymphocytes. J. Immunol. Methods 2011, 364:94-100

Somerville RP, Devillier L, Parkhurst MR, Rosenberg SA, Dudley ME: Clinical scale rapid expansion of lymphocytes for adoptive cell transfer therapy in the WAVE(R) bioreactor. J. Transl. Med. 2012, 10:69.

45. - Almåsbak H, Walseng E, Kristian A, Myhre MR, Suso EM, Munthe LA, Andersen JT, Wang MY, Kvalheim G, Gaudernack G, et al.: Inclusion of an IgG1-Fc spacer abrogates efficacy of CD19 CAR T cells in a xenograft mouse model. Gene Ther. 2015, 22:391-403.

The authors produced CAR T cells by mRNA transient transfection and were thus able to create T cells that temporarily express the CAR transgene. Further, they found that a frequently used spacer hampered anti-leukaemia activity and induced toxicity in their construct, highlighting the need to understand the role of non-signalling CAR elements.

46. Barrett DM, Zhao Y, Liu X, Jiang S, Carpenito C, Kalos M, Carroll RG, June CH, Grupp SA: Treatment of Advanced Leukemia in Mice with mRNA Engineered T Cells. Hum. Gene Ther. 2011, 22:1575-1586.

Beatty GL, Haas AR, Maus M V, Torigian DA, Soulen MC, Plesa G, Chew A, Zhao Y, Levine BL, Albelda SM, et al.: Mesothelin-specific chimeric antigen receptor mRNAengineered T cells induce anti-tumor activity in solid malignancies. Cancer Immunol. Res. 2014, 2:112-120.

Di Stasi A, Tey S-K, Dotti G, Fujita Y, Kennedy-Nasser A, Martinez C, Straathof K, Liu E, Durett AG, Grilley B, et al.: Inducible apoptosis as a safety switch for adoptive cell therapy. N. Engl. J. Med. 2011, 365:1673-83. 
Gardner R et al.: CD19CAR T Cell Products of Defined CD4:CD8 Composition and Transgene Expression Show Prolonged Persistence and Durable MRD-Negative Remission in Pediatric and Young Adult B-Cell ALL. Blood 2016, 128:219.

.• Fesnak AD, June CH, Levine BL: Engineered T cells: the promise and challenges of cancer immunotherapy. Nat Rev Cancer 2016, 16:566-581.

This review provides a great insight into some key challenges in the field of CAR-T cell therapy, such as the targeting of non-B cell malignancies and increasing precision. It also describes promising advances that have been made in the design of CARs to overcome these challenges. There is a particularly interesting focus here on what future CAR-T cell therapies are likely to involve.

Dai H, Zhang W, Li X, Han Q, Guo Y, Zhang Y, Wang Y, Wang C, Shi F, Zhang Y, et al.: Tolerance and efficacy of autologous or donor-derived T cells expressing CD19 chimeric antigen receptors in adult B-ALL with extramedullary leukemia. Oncoimmunology 2015, 4:e1027469-1-12.

Porter DL, Hwang W, Frey N V, Lacey SF, Shaw P a, Loren AW, Bagg A, Marcucci KT, Shen A, Gonzalez V, et al.: Chimeric antigen receptor T cells persist and induce sustained remissions in relapsed refractory chronic lymphocytic leukemia. Sci. Transl. Med. 2015, 7:303ra139.

Sadelain M, Brentjens R, Rivière I: The Basic Principles of Chimeric Antigen Receptor Design. Cancer Discov. 2013, 3:388 LP-398.

Abate-Daga D, Davila ML: CAR models: Next-generation CAR modifications for enhanced T-cell function. Mol. Ther. - Oncolytics 2016, 3:16014.

Jaspers JE, Brentjens RJ: Development of CAR T cells designed to improve antitumor efficacy and safety. Pharmacol. Ther. 2017, 178:83-91.

Lee DW, Kochenderfer JN, Stetler-Stevenson M, Cui YK, Delbrook C, Feldman SA, Fry TJ, Orentas R, Sabatino M, Shah NN, et al.: T cells expressing CD19 chimeric antigen receptors for acute lymphoblastic leukaemia in children and young adults: A phase 1 dose-escalation trial. Lancet 2015, 385:517-528. Gee AP: Manufacturing genetically modified T cells for clinical trials. Cancer Gene Ther. 2015, 22:1-5. Skrdlant LM, Armstrong RJ, Keidaisch BM, Lorente MF, DiGiusto DL: Detection of Replication Competent Lentivirus Using a qPCR Assay for VSV-G. Mol. Ther. - Methods Clin. Dev. 2017, 8:1-7.

Liu L, Sommermeyer D, Cabanov A, Kosasih P, Hill T, Riddell SR: Inclusion of Strep-Tag II in design of antigen receptors for T cell immunotherapy. Nat. Biotechnol. 2016, 34:430-434.

Quintarelli C, Locatelli F, Caruana I, De Angelis B: Overcoming Challenges in CAR T-cell Product CGMP Release. Mol. Ther. 2016, 24:845-846. Kelley B: Industrialization of mAb production technology The bioprocessing industry at a crossroads. MAbs 2009, 1:443-452.

Kochenderfer JN, Dudley ME, Carpenter RO, Kassim SH, Rose JJ, Telford W, Hakim FT, Halverson D, Fowler DH, Hardy NM, et al.: Donor-Derived Anti-CD19 ChimericAntigen-Receptor-Expressing T Cells Cause Regression Of Malignancy Persisting After Allogeneic Hematopoietic Stem Cell Transplantation. Blood 2013, 122:151. Bonifant CL, Jackson HJ, Brentjens RJ, Curran KJ: Toxicity and management in CAR T-cell therapy. Mol. Ther. - Oncolytics 2016, 3:16011. Yang Y, Jacoby E, Fry TJ: Challenges and opportunities of allogeneic donor-derived CAR T cells. Curr. Opin. Hematol. 2015, 22:509-515. - Poirot L, Philip B, Schiffer-Mannioui C, Le Clerre D, Chion-Sotinel I, Derniame S, Bas C, Potrel P, Lemaire L, Duclert A, et al.: Multiplex genome edited T-cell manufacturing platform for "off-the-shelf" adoptive T-cell immunotherapies. Cancer Res. 2015, 75:3853-3864

In this paper, Poirot et al. describe a gene editing method, i.e. TALEN, to inactivate the T cell $\alpha$ and $\beta$ chain of unrelated donor-derived CAR T cells. This allows engraftment of cells that do not evoke graft-versus-host-disease. They further inactivated CD52, a target for the chematherapeutic alemtuzumab, that can thus be administered to

support the engraftment of the CAR T cells and the therapy.
Qasim W, Zhan H, Samarasinghe S, Adams S, Amrolia P, Stafford S, Butler K, Rivat C, Wright G, Somana K, et al.: Molecular remission of infant B-ALL after infusion of universal TALEN gene-edited CAR T cells. Sci. Transl. Med. 2017, 9

•• Mock U, Nickolay L, Philip B, Cheung GW-K, Zhan H, Johnston ICD, Kaiser AD, Peggs K, Pule M, Thrasher AJ, et al.: Automated manufacturing of chimeric antigen receptor T cells for adoptive immunotherapy using CliniMACS Prodigy. Cytotherapy 2016, 18:1002-1011.

Mock and colleagues applied the CliniMACS Prodigy, an automateted cell therapy manufacturing platform, for the production of clinically relevant numbers of CAR T cells. They showed that production in the clinical setting is feasible and that man hours can be significantly reduced using this platform.

Mitsuyasu RT, Anton PA, Deeks SG, Scadden DT, Connick E, Downs MT, Bakker A, Roberts MR, June CH, Jalali S, et al.: Prolonged survival and tissue trafficking following adoptive transfer of CD4zeta gene-modified autologous CD4(+) and CD8(+) T cells in human immunodeficiency virus-infected subjects. Blood 2000, 96:785-793. Louis CU, Savoldo B, Dotti G, Pule M, Yvon E, Myers GD, Rossig C, Russell H V, Diouf O, Liu E, et al.: Antitumor activity and long-term fate of chimeric antigen receptor positive T cells in patients with neuroblastoma. Blood 2011, 118:6050-6.

Pule MA, Savoldo B, Myers GD, Rossig C, Russell H V, Dotti G, Huls MH, Liu E, Gee AP, Mei Z, et al.: Virus-specific T cells engineered to coexpress tumor-specific receptors: persistence and antitumor activity in individuals with neuroblastoma. Nat. Med. 2008, 14:1264-1270.

Junghans RP, Ma Q, Rathore R, Gomes EM, Bais AJ, Lo ASY, Abedi M, Davies RA, Cabral HJ, Al-Homsi AS, et al.: Phase I Trial of Anti-PSMA Designer CAR-T Cells in Prostate Cancer: Possible Role for Interacting Interleukin 2-T Cell Pharmacodynamics as a Determinant of Clinical Response. Prostate 2016, 76:1257-1270.

Till BG, Jensen MC, Wang J, Qian X, Gopal AK, Maloney DG, Lindgren CG, Lin Y, Pagel JM, Budde LE, et al.: antigen receptor with both CD28 and 4-1BB domains : pilot clinical trial results CD20-specific adoptive immunotherapy for lymphoma using a chimeric antigen receptor with both CD28 and 4-1BB domains : pilot clinical trial results. 2014, 119:3940-3950.

Savoldo B, Ramos CA, Liu E, Mims MP, Keating MJ, Carrum G, Kamble RT, Bollard CM, Gee AP, Mei Z, et al.: CD28 costimulation improves expansion and persistence of chimeric antigen receptor-modified T cells in lymphoma patients. J. Clin. Invest. 2011, 121:1822-1826.

Kochenderfer JN, Wilson WH, Janik JE, Dudley ME, Feldman S a, Maric I, Raffeld M, Nathan DN, Brock J, Morgan R a, et al.: Eradication of B-lineage cells and regression of lymphoma in a patient treated with autologous $T$ cells genetically engineered to recognize Brief report Eradication of $B$-lineage cells and regression of lymphoma in a patient treated with autologous T cells. 2010, 116:4099-4102.

Johnson LA, Morgan RA, Dudley ME, Cassard L, Yang JC, Hughes MS, Kammula US, Royal RE, Sherry RM, Wunderlich JR, et al.: Gene therapy with human and mouse T-cell receptors mediates cancer regression and targets normal tissues expressing cognate antigen. Blood 2009, 114:535-546.

Kochenderfer JN, Dudley ME, Feldman SA, Wilson WH, Spaner DE, Maric I, Stetler-Stevenson M, Phan GQ, Hughes MS, Sherry RM, et al.: B-cell depletion and remissions of malignancy along with cytokine-associated toxicity in a clinical trial of anti-CD19 chimeric-antigen-receptor-transduced T cells. Blood 2012, 119:2709-2720.

Kochenderfer JN, Dudley ME, Kassim SH, Somerville RPT, Carpenter RO, Maryalice SS, Yang JC, Phan GQ, Hughes MS, Sherry RM, et al.: Chemotherapy-refractory diffuse large B-cell lymphoma and indolent B-cell malignancies can be effectively treated with autologous T cells expressing an anti-CD19 chimeric antigen receptor. J. Clin. Oncol. 2015, 33:540-549.

Porter DL, Levine BL, Kalos M, Bagg A, June CH: Chimeric antigen receptor-modified T cells in chronic lymphoid leukemia. N Engl J Med 2011, 365:725-733. Ritchie DS, Neeson PJ, Khot A, Peinert S, Tai T, Tainton K, Chen K, Shin M, Wall DM, Honemann D, et al.: Persistence and efficacy of second generation CAR T cell against the LeY antigen in acute myeloid leukemia. Mol Ther 2013, 21:2122-2129.

Brentjens RJ, Davila ML, Riviere I, Park J, Wang X, Cowell LG, Bartido S, Stefanski J, Taylor C, Olszewska M, et al.: CD19-targeted T cells rapidly induce molecular remissions in adults with chemotherapy-refractory acute lymphoblastic leukemia. Sci. Transl. Med. 2013, 5:177ra38.

Davila ML, Riviere I, Wang X, Bartido S, Park J, Curran K, Chung SS, Stefanski J, Borquez-Ojeda O, Olszewska M, et al.: Efficacy and toxicity management of 19-28z CAR T cell therapy in B cell acute lymphoblastic leukemia. Sci. Transl. Med. 2014, 6:224ra25.

Brudno JN, Somerville RPT, Shi V, Rose JJ, Halverson DC, Fowler DH, Gea-Banacloche JC, Pavletic SZ, Hickstein DD, Lu TL, et al.: Allogeneic T Cells That Express an Anti-CD19 Chimeric Antigen Receptor Induce Remissions of B-Cell Malignancies That Progress After Allogeneic Hematopoietic Stem-Cell Transplantation Without Causing GraftVersus-Host Disease. J. Clin. Oncol. 2016, 34:1112-1121.

Grupp SA, Kalos M, Barrett D, Aplenc R, Porter DL, Rheingold SR, Teachey DT, Chew A, Hauck B, Wright JF, et al.: Chimeric antigen receptor-modified T cells for acute lymphoid leukemia. N Eng/ J Med 2013, 368:1509-1518.

Maude SL, Frey N, Shaw PA, Aplenc R, Barrett DM, Bunin NJ, Chew A, Gonzalez VE, Zheng Z, Lacey SF, et al.: Chimeric Antigen Receptor T Cells for Sustained Remissions in Leukemia. N. Engl. J. Med. 2014, 371:1507-1517.

Wang Y, Zhang W ying, Han Q wang, Liu Y, Dai H ren, Guo Y lei, Bo J, Fan H, Zhang Y, Zhang Y jing, et al.: Effective response and delayed toxicities of refractory advanced Wang Y, Zhang W ying, Han Q wang, Liu Y, Dai H ren, Guo Y lei, Bo J, Fan H, Zhang Y, Zhang Y jing, et al.: Effective response and delayed toxic
diffuse large B-cell lymphoma treated by CD20-directed chimeric antigen receptor-modified T cells. Clin. Immunol. 2014, 155:160-175. - Turtle CJ, Hanafi L-A, Berger C, Gooley TA, Cherian S, Hudecek M, Sommermeyer D, Melville K, Pender B, Budiarto TM, et al.: CD19 CAR-T cells of defined CD4(+):CD8(+) composition in adult B cell ALL patients. J. Clin. Invest. 2016, 126:2123-2138.

The authors conducted the first clinical trial in which patients received a CD19 CAR-T cell treatment with a defined CD4+:CD8+ composition. Here they report a $93 \%$ rate of bone marrow remission from 29 treated patients with relapsed and refractory B cell acute lymphoblastic leukaemia. Moreover, they were able to produce a CAR-T cell product with a 1:1 ratio of CD4+:CD8+ for 27 out of 30 patients, demonstrating the feasibility of selecting defined T cell subsets to produce a more defined CAR-T cell product.

Wang Q-S, Wang Y, Lv H-Y, Han Q-W, Fan H, Guo B, Wang L-L, Han W-D: Treatment of CD33-directed Chimeric Antigen Receptor-modified T Cells in One Patient With Wang Q-S, Wang Y, LV H-Y, Han Q-W, Fan H, Guo B, Wang L-L, Han W-D: Treatment
Relapsed and Refractory Acute Myeloid Leukemia. Mol. Ther. 2015, 23:184-91.

Gardner RA, Finney O, Annesley C, Brakke H, Summers C, Leger K, Bleakley M, Brown C, Mgebroff S, Kelly-Spratt KS, et al.: Intent-to-treat leukemia remission by CD19 CAR T cells of defined formulation and dose in children and young adults. Blood 2017, 129:3322 LP-3331. 